University of Nebraska - Lincoln

DigitalCommons@University of Nebraska - Lincoln

Faculty Publications in Food Science and Technology

Food Science and Technology Department

2007

\title{
Extraction and Characterization of Starch from Alkaline Cooked Corn Masa
}

Wajira Srinanda Ratnayake

University of Nebraska-Lincoln

Andrew B. Wassinger

University of Nebraska-Lincoln

David S. Jackson

University of Nebraska-Lincoln, djackson1@unl.edu

Follow this and additional works at: https://digitalcommons.unl.edu/foodsciefacpub

Part of the Food Science Commons

Ratnayake, Wajira Srinanda; Wassinger, Andrew B.; and Jackson, David S., "Extraction and Characterization of Starch from Alkaline Cooked Corn Masa" (2007). Faculty Publications in Food Science and Technology. 104.

https://digitalcommons.unl.edu/foodsciefacpub/104

This Article is brought to you for free and open access by the Food Science and Technology Department at DigitalCommons@University of Nebraska - Lincoln. It has been accepted for inclusion in Faculty Publications in Food Science and Technology by an authorized administrator of DigitalCommons@University of Nebraska - Lincoln. 


\title{
Extraction and Characterization of Starch from Alkaline Cooked Corn Masa ${ }^{1}$
}

\author{
Wajira S. Ratnayake, ${ }^{2}$ Andrew B. Wassinger, ${ }^{2}$ and David S. Jackson ${ }^{2,3}$
}

\section{ABSTRACT}

Cereal Chem. 84(4):415-422

Starch granules undergo structural and morphological changes during food processing unit operations as they interact with other food ingredients. This study was conducted to isolate and characterize starch granules from corn masa. A proteolytic enzyme, thermolysin, was effective in separating and isolating starch granules from endosperm proteins present in masa. The efficiency of starch extraction using thermolysin was $74 \%$ $(w / w)$, and subsequent analyses showed that the isolated granules were free of contaminants. Starch samples were characterized using light microscopy, SEM, DSC, and XRD. Starch granules isolated from masa had undergone internal structural changes and some granules $(\approx 40 \%)$ lost birefringence during nixtamalization. These internal changes occurred, in most cases, without visible alterations in general granular morphology. Nixtamalized granules underwent changes mostly consistent with a "heatmoisture treatment" process.
Physiochemical properties of food starches have been studied extensively (Zobel 1984; Biliaderis 1998; Jacobs and Delcour 1998; Jenkins and Donald 1998; Sahai and Jackson 1999; Liu et al 2002). Starch in foods, exposed to specific hydrothermal conditions, would not necessarily undergo the same structural and morphological changes as would isolated starch (starch relatively free of proteins, lipids, etc.) exposed to the same treatment. Starch properties and food functionality depend on the type (or source) of starch, and food composition. Food components such as protein, fatty acids, and various solutes affect the thermal behavior of starch; this has been documented by various studies conducted using predetermined mixtures of starch and other ingredients (Larsson 1980; Lund and Lorenz 1984; Eliasson 1985; Lim et al 2000; Bogracheva et al 2002; Gonera and Cornillon 2002; Gibbon et al 2003; Tolstoguzov 2003; Zhang and Hamaker 2003; Zhang et al 2003; Lindeboom et al 2004; Mondragon et al 2004; Kar et al 2005; Rumpold and Knorr 2005; Sayer et al 2005). Because of inherent difficulties associated with starch isolation from actual processed food products, knowledge of the structural changes that occur during hydrothermal treatments and starch-food component interactions is poorly understood.

Alkaline cooking, which is referred to as nixtamalization, is an important process used in the preparation of tortillas, corn chips, taco shells, tamales, and other Mexican-style foods. During nixtamalization, corn is first cooked in the presence of lime, steeped, and then washed to produce nixtamal. Nixtamal is stone-ground to form a soft, moist dough that is called masa (Gomez et al 1987; Serna-Saldivar et al 1990). Although nixtamalization is widely used in the food industry, a comprehensive, fundamental understanding of starch functionality and its thermal behavior in masa is still lacking. The starch gelatinization process during masa preparation has not been studied in detail, and only a few reports are available on the effect of masa components on starch functionality (Bryant and Hamaker 1997; Campus-Baypoli et al 1999). Starch in masa has been characterized without extracting starch in purified form (Gomez et al 1991, 1992). Although these studies are helpful in identifying changes in starch granules during masa

\footnotetext{
${ }^{1}$ A contribution of the University of Nebraska Agricultural Research Division (Journal Series Number 15264), supported in part by funds provided through the Hatch Act. Names are necessary to report factually on available data; however, the USDA neither guarantees nor warrants the standard of the product, and the use of the name by the USDA implies no approval of the product to the exclusion of others that may also be suitable.

${ }^{2}$ Department of Food Science and Technology, University of Nebraska-Lincoln. Lincoln, NE 68583-0919.

${ }^{3}$ Corresponding author. Phone: 402-472-2814. Fax: 402-472-1693. E-mail address: djackson@unlnotes.unl.edu
}

doi: $10.1094 / C C H E M-84-4-0415$

This article is in the public domain and not copyrightable. It may be freely reprinted with customary crediting of the source. AACC International, Inc., 2007. production, the influence of the other components in masa during starch analyses cannot be completely eliminated. There are no highly effective methods available to isolate starch from masa. Starch isolation is an important first analytical step in evaluating the structural changes starch granules undergo during nixtamalization. The objectives of this study were to isolate starch granules from freshly prepared masa and to investigate morphological and structural changes of these extracted starch granules.

\section{MATERIALS AND METHODS}

A white food corn (Hybrid Zimmerman 1851W, 2000 crop year) was obtained from Wilson Genetics LLC. (Harlan, IA) [Now available from Garst Seed Company, Slater, IA]. The grain was stored at $-16^{\circ} \mathrm{C}$ before use.

\section{Grain Composition Analysis}

Proximate composition of whole corn was analyzed using the Official Methods 920.39, 935.29, and 942.05 (AOAC International 2004).

\section{Starch Extraction from Corn Kernels}

Starch from the food corn was extracted using a laboratory wetmilling procedure: corn was steeped at $51 \pm 1{ }^{\circ} \mathrm{C}$ for $48 \mathrm{hr}$ with $0.47 \%(\mathrm{w} / \mathrm{v})$ lactic acid and $0.15 \%(\mathrm{w} / \mathrm{v})$ sodium bisulfite. This procedure is more fully outlined by Wehling et al (1993). In addition, a small amount of endosperm starch (raw starch) used for selected DSC experiments was physically scraped from corn kernels that had been cracked open.

\section{Masa Preparation}

Nixtamal and masa were produced using the method developed by Yglesias et al (2005), which mimics the industrial-scale masa production process. Corn was cooked for $30 \mathrm{~min}$ at $90^{\circ} \mathrm{C}$ and steeped for $9.5 \mathrm{hr}$. Starch in masa was stabilized and preserved using a liquid nitrogen freeze-drying method previously documented to create minimal changes from the fresh state (Yglesias and Jackson 2005). Samples were stored in sealed polypropylene containers at $-18^{\circ} \mathrm{C}$ until further analyses.

\section{Starch Extraction from Masa}

Starch from masa was extracted using two different methods. For Method 1, freeze-dried masa was ground into flour using a cyclone sample mill (model 3010-030, Udy Co., Fort Collins, $\mathrm{CO}$ ). Masa (10 g) was dispersed in $500 \mathrm{~mL}$ of distilled water by stirring using a magnetic stirrer for $6 \mathrm{hr}$. The mixture was passed through a loose cotton wool plug in a funnel and then it was filtered using a $60-\mu \mathrm{m}$ polyester mesh screen (Spectrum Laboratories, Rancho Dominguez, CA) under suction to remove coarse particles. The filtrate containing starch was collected and washed with 
distilled water containing $1 \%(\mathrm{w} / \mathrm{v})$ sodium hydroxide four times and then washed with distilled water several times. The recovered starch was dispersed in $500 \mathrm{~mL}$ of distilled water and filtered using $10-\mu \mathrm{m}$ nylon mesh (Spectrum Laboratories) under suction to remove fine contaminants. Starch was recovered and freezedried (Virtis Sentry $8 \mathrm{~L}$ freeze dryer, SP Industries, Gardiner, NY) at $-55^{\circ} \mathrm{C}$ and $200 \mathrm{mT}$ Torr pressure for $36 \mathrm{hr}$. Samples were stored in sealed polypropylene containers until used.

For Method 2, dried masa was ground into flour using a cyclone sample mill (Udy model 3010-030). Starch in masa was extracted by the protease digestion method described by $\mathrm{Mu}-$ Forster and Wasserman (1998), with slight modifications. Dry masa flour $(5 \mathrm{~g}$ ) was mixed with 330 units of thermolysin (from Bacillus thermoproteolyticus Rokko [EC 3.4.24.27], SigmaAldrich, Steinheim) in the presence of $5 \mathrm{~m} M$ calcium chloride in $100 \mathrm{~mL}$ of aqueous solution in a 125-mL screw-cap Erlemmeyer flask. The mixture was kept in a $60^{\circ} \mathrm{C}$ water bath for $4 \mathrm{hr}$ and gently hand-mixed at 30-min intervals. The enzyme action was terminated by adding $0.03 \mathrm{~g}$ of EDTA to the reaction mixture. After cooling to room temperature, the mixture was filtered through a loose cotton wool plug in a funnel to remove coarse particles and washed five times with distilled water to remove residual proteins. Starch was recovered by centrifuging the suspension at $1,300 \times g$ for 7 min (model RC-3, Ivan Sorvall, Norwalk, CT) after each washing step. Recovered starch was redispersed in $500 \mathrm{~mL}$ of distilled water and filtered using a $60-\mu \mathrm{m}$ polyester mesh screen (Spectrum Laboratories) under suction to remove coarse particles. The filtrate containing starch was collected and washed with distilled water containing $1 \%(\mathrm{w} / \mathrm{v})$ sodium hydroxide four times and then washed with distilled water several times. Recovered starch was dispersed in $500 \mathrm{~mL}$ of distilled water and filtered using a 10- $\mu \mathrm{m}$ nylon mesh screen (Spectrum Laboratories) under suction to remove fine contaminants and freeze-dried using a freeze dryer (Virtis Sentry $8 \mathrm{~L}$, SP industries, Gardiner, NY) at $-50^{\circ} \mathrm{C}$ and 100 mTorr vacuum pressure for 36 hr. Samples were stored in sealed polypropylene containers until used.

\section{Masa Protein}

Total protein contents (total nitrogen $\times 6.25$ ) of masa and isolated starch samples were analyzed by the Dumas combustion procedure using a nitrogen determinator (FP-528, Leco Corporation, St. Joseph, MI). The equipment was calibrated using EDTA.

\section{Total Starch in Masa}

Masa samples were dispersed by adding $10 \mathrm{~mL}$ of $2 N$ sodium hydroxide to $0.5 \mathrm{~g}$ of masa in $70-\mathrm{mL}$ capacity test tubes and heated for $25 \mathrm{~min}$ at $94^{\circ} \mathrm{C}$ and adjusted to $\mathrm{pH} 4.5$ using $2 \mathrm{~N}$ hydrochloric acid and $10 \mathrm{~mL}$ of acetate buffer $(9.1 \mathrm{~g}$ of sodium acetate [Sigma Chemical Co., St. Louis, MO] and $44.6 \mathrm{~mL}$ of glacial acetic acid [Fisher Scientific, Pittsburg, PA] diluted to 500 $\mathrm{mL}$ ). Amyloglucosidase [EC 3.2.1.3] (300 units, Sigma Chemical) was added and the slurry was incubated for $70 \mathrm{~min}$ at $50^{\circ} \mathrm{C}$. The reaction was terminated by adding $5 \mathrm{~mL}$ of $25 \%(\mathrm{v} / \mathrm{v})$ trichloroacetic acid (Fisher Scientific, Pittsburg, PA) and the volume was adjusted to $100 \mathrm{~mL}$ in a volumetric flask using phosphate buffer (40 $\mathrm{g}$ of anhydrous monobasic sodium phosphate, anhydrous [Fisher Scientific] and $10 \mathrm{~g}$ of anhydrous dibasic sodium phosphate [Sigma] diluted to $1 \mathrm{~L}$ ). Glucose concentration was measured using a biochemistry analyzer (model 2700 Select, YSI, Yellow Springs, $\mathrm{OH}$ ) fitted with an immobilized glucose oxidase membrane [EC 1.1.3.4] in the presence of phosphate buffer (YSI 2357 buffer concentrate kit). Percent total starch (dry basis) was calculated using this equation:

Total starch $(\%)=\{[$ Glucose in sample $(\mathrm{g} / \mathrm{L})-$ Blank $\mathrm{A}$ Blank B] $\times 0.9 \times 0.10 \times 100\} /$ Sample weight $(\mathrm{g})$, where Blank A is the amount of free glucose in sample $(\mathrm{g} / \mathrm{L})$ and Blank $B$ is the enzyme blank ( $\mathrm{g} / \mathrm{L})$.
The blanks A and B were used to correct the sample reading for free glucose in the sample and the amyloglucosidase reagent, respectively. Conversion factors were used to convert glucose into starch $(0.9)$ and convert units of volume $(0.10)$. The analyzer was calibrated using a D-glucose standard $(2.50 \mathrm{~g} / \mathrm{L}$, YSI 2776 solution).

\section{Starch Yield and Isolation Efficiency}

Starch yield was calculated as: Starch yield $(\%)=\{[$ Weight of isolated starch $(\mathrm{g}) \times 100 \%] /$ Weight of the corn sample $(\mathrm{g})\}$.

The starch isolation efficiency was calculated as: Starch isolation efficiency $=\{$ [Weight of isolated starch $(\mathrm{g}) \times 100 \%] /$ Total starch in corn sample $(\mathrm{g})\}$

\section{Light Microscopy of Masa}

Masa samples $(\approx 0.10 \mathrm{~g}$ of sample in $\approx 15 \mathrm{~mL}$ of water) were heated to specific temperatures in a glass petri dish placed on a laboratory electric hot plate while monitoring the temperature with a noncontact infrared thermometer. The heated sample in the petri dish was promptly observed under a microscope (Provis AX70, Olympus America, Melville, NY) equipped with a $60 \times$ water immersion lens (600) magnification) and a camera (Optronics, Goleta, CA) attached to the eye piece. Digital images were captured using software (v.2.1C, MagnaFire, Optronics).

\section{Polarized Light Microscopy of Starch}

A small amount $(\approx 0.005 \mathrm{~g})$ of starch was mounted on a glass slide with a few drops of water and covered with a cover slip. The mounted sample was then observed under polarized light (polarizers at $90^{\circ}$ to light path) using a microscope (Optiphot, Nikon USA, Melville, NY) and a lens converter (model MD, Meiji Techno Co., Saitama, Japan) equipped with polarizing filters at the light source and lens piece (Fisher Scientific, Pittsburgh, PA). Images were captured using a Sony video imaging system (model VPC 920 adapter and PVM-1354Q monitor) and a Sony photo printer (Mavigraph UP-1200A).

\section{Scanning Electron Microscopy (SEM)}

Masa and isolated starch samples were mounted on metal stubs and coated with gold palladium $(\approx 20 \mathrm{~nm}$ thickness) using a Hummer sputter-coating system (Anatech Ltd., Union City, CA). Samples were then observed using a scanning electron microscope (S3000 N, Hitachi Science Systems, Tokyo) at an acceleration potential of $15 \mathrm{kV}$. Pictures were captured using automated image capturing software (Hitachi High-Technologies, Pleasanton, CA).

\section{Differential Scanning Calorimetry (DSC)}

Starch and masa samples $(\approx 10 \mathrm{mg}, \mathrm{db})$ with $\approx 55 \mu \mathrm{L}$ of distilled water (i.e., starch in excess water) were hermetically sealed in DSC pans (Perkin Elmer Pan Sell Kit 0319-1525/1526/1535) and kept at room temperature for 2-3 hr. Next, samples were scanned against a blank (empty pan) using a Perkin Elmer Pyris 1 differential scanning calorimeter from 25 to $90^{\circ} \mathrm{C}$ at a $10^{\circ} \mathrm{C} / \mathrm{min}$ scanning rate. Pyris v.3.52 software (Perkin Elmer) was used to collect onset $\left(T_{\mathrm{o}}\right)$, peak $\left(T_{\mathrm{p}}\right)$, and end $\left(T_{\mathrm{c}}\right)$ temperatures, and the transition enthalpy $(\Delta H)$. Equipment was calibrated using indium as the reference material.

\section{X-ray Diffraction (XRD)}

X-ray diffraction data were obtained using a Bruker-AXS D8 Discover XRD system (Bruker AXS Microanalysis GmbH, Berlin) with a general area detector diffraction system (GADDS). The system was equipped with a copper target X-ray tube set to $40 \mathrm{kV}$ and $30 \mathrm{~mA}$, a Gobel mirror, a $0.5-\mathrm{mm}$ pinhole collimator, and a Bruker-AXS HI-Star area detector. The samples were mounted on an aluminum sample plate with a few drops of ethanol and compressed using a glass slide to obtain a smooth surface. The mounted samples were allowed to dry at room temperature for $\approx 20 \mathrm{~min}$ before scanning. Sample surfaces were aligned to the cen- 
ter of the X-ray beam using a laser/video microscope system. Data were collected in reflection mode using the scan conditions of Omega $=4$ degrees, detector swing angle $=18$ degrees, sample to detector distance $=9.75 \mathrm{~cm}$, exposure time $=180 \mathrm{sec}$. Area detector data were processed using Bruker-AXS GADDS system software by integrating over $2 \theta=7$ to 35 degrees and $\chi=-130$ to -50 degrees. The integration was conducted along the Debye rings resulting in a diffractogram of intensity versus $2 \theta$.

Percent relative crystallinity was calculated according to the method outlined by Nara et al (1978) using quartz as $100 \%$ crystalline material (Eliasson et al 1987) and an $85^{\circ} \mathrm{C}$ treated sample of each starch as $100 \%$ amorphous material. Peak fitting software (v.6.0/SR-4, Microcal Software, Northhampton, MA) was used to calculate absolute differences between XRD profiles. The percentage relative crystallinity was calculated as \% Relative crystallinity $=\left[\left(\sum\left|I_{s}-I_{a}\right| / \sum\left|I_{c}-I_{a}\right|\right) \times 100 \%\right]$ where $\left|I_{s}-I_{a}\right|=$ absolute difference between the sample $\left[I_{s}\right]$ and amorphous $\left[I_{a}\right]$ intensities, and $\left|I_{c}-I_{a}\right|=$ absolute difference between the crystalline (quartz) $\left[I_{c}\right]$ and amorphous $\left[I_{a}\right]$ intensities.

\section{Statistical Analyses}

All results are averages of at least three independent replicates. Mean separations were performed using the Tukey-Kramer HSD test using JMP v.5.0.1.2 software (SAS Institute, Cary, NC).

\section{RESULTS AND DISCUSSION}

The proximate composition of the corn used in this study is given in Table I. Several previous studies have shown that the proteolytic enzyme thermolysin can be successfully used to remove proteins associated with starch granules (Belles et al 2000; MezoVillanueva and Serna-Saldivar 2004; Han et al 2005). Accordingly, thermolysin digestion was used to remove starch granules from protein matrices in masa. Starch isolated by Method 2 (enzyme digestion) gave starch with significantly $(P<0.05)$ less protein compared with the control (Method 1). The total protein contents were 4.7 and $0.74 \%(w / w)$ in starches isolated by Methods 1 and 2 , respectively. Total protein in masa was $11.13 \%(\mathrm{w} / \mathrm{w})$, which was slightly higher than published values of $8.4-9.5 \%$ adjusted for the 6.25 conversion factor (Bello-Perez et al 2003) and $8.8 \%$ (Yglesias et al 2005). According to these results, $\approx 57.7 \%$ of protein in masa can be removed by water washing (Method 1), and the rest of the starch granule bound proteins $(\approx 35.6 \% \%)$ are removed by thermolysin action (Method 2 ). A very small amount $(\approx 6.5 \%)$ of total protein in masa is left with purified starch granules after thermolysin treatment. In SEM images (Fig. 1), protein and endosperm remnants were clearly visible among starch granules isolated by Method 1, whereas digesting protein with thermolysin (Method 2) resulted in relatively "uncontaminated" starch granules. The starch yield of thermolysin extraction (weight of granules extracted from masa) was $60.0 \%$ (w/w, SD 2\%). The starch extraction efficiency of the method was $74 \%(w / w, d b)$ based on amount of starch in masa.

TABLE I

Composition of White Food-Grade Corn Kernels Used to Prepare Wet-Milled Starch and Masa

\begin{tabular}{lc}
\hline Component & Amount (\% dry basis) \\
\hline Total starch $^{\mathrm{a}}$ & $72.3 \pm 0.5$ \\
Moisture $^{\mathrm{b}, \mathrm{c}}$ & $8.8 \pm 0.3$ \\
Crude protein $^{\mathrm{b}}$ & $9.7 \pm 0.3$ \\
Crude fiber $^{\mathrm{b}}$ & $3.5 \pm 0.2$ \\
Crude fat $^{\mathrm{b}}$ & $3.3 \pm 0.3$ \\
Ash $^{\mathrm{b}}$ & $1.3 \pm 0.2$ \\
\hline
\end{tabular}

${ }^{a}$ By the Dumas combustion method.

${ }^{\mathrm{b}}$ According to AOAC International (2004) approved methods.

${ }^{c}$ As received.
Polarized light microscopy (Fig. 2) revealed that most of the starch granules retained birefringence throughout the masa preparation process and starch isolation. Water extraction (Method 1) presumably affects starch granule characteristics less than Method 2 (thermolysin treatment) because Method 2 involves heating during the enzyme digestion process. However, there were no observable differences between the percentage of granules exhibiting birefringence in starch samples isolated by these two methods. According to our observations, masa contains a mixture of starch granules in which $\approx 60 \%$ granules do not show birefringence and
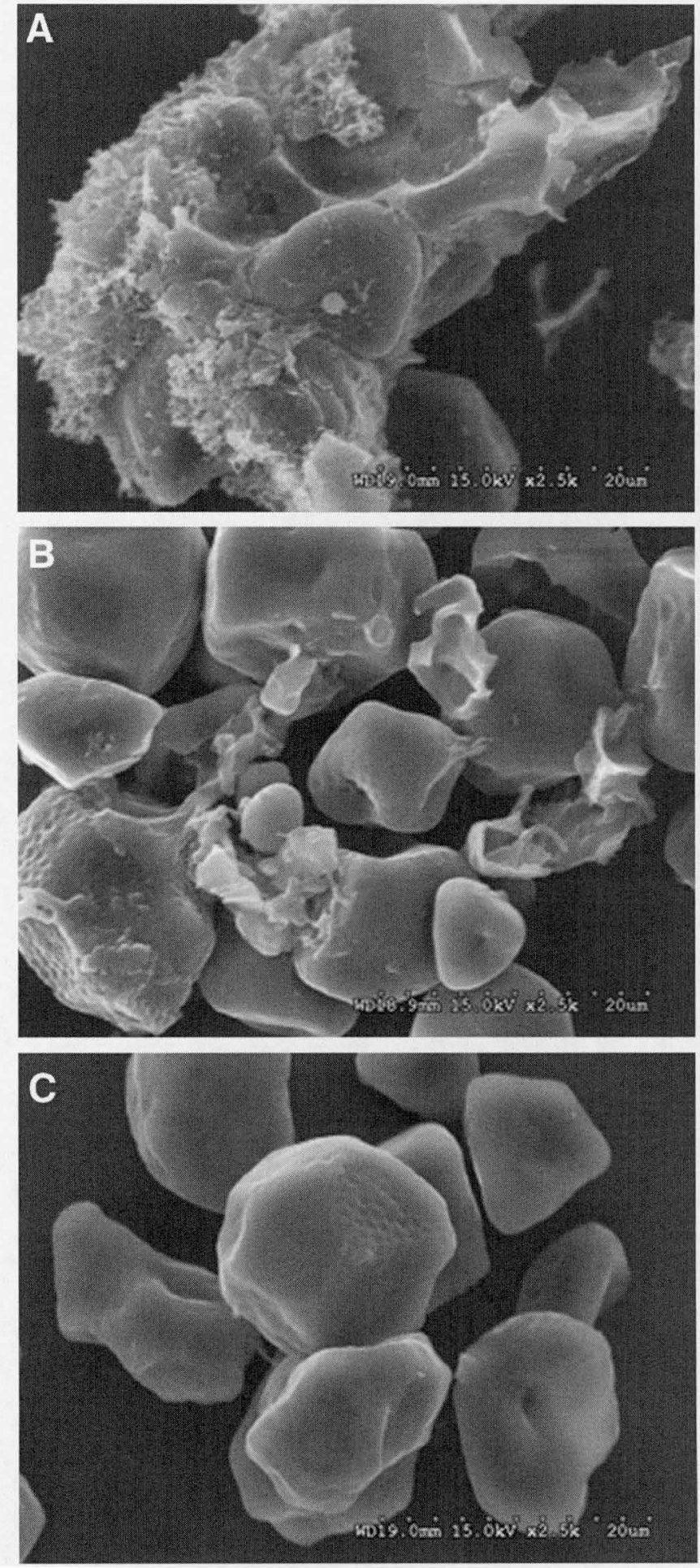

Fig. 1. Scanning electron microscopic images of masa (A), starch isolated by Method 1 (B), and starch isolated by Method 2 (C). Magnification $2,500 x$. 
$\approx 40 \%$ granules show birefringence. These results are in agreement with previously published reports that indicate many starch granules in masa retain their birefringent properties (Gomez et al 1989; Serna-Saldivar et al 1990).

Loss of birefringence indicates a loss of molecular order and general molecular organization within starch granules. During reheating in excess water (Fig. 3), these processed masa starch granules behaved in a manner similar to regular corn starch granules (Ratnayake and Jackson 2006). Most granules were swollen at $55-60^{\circ} \mathrm{C}$ and they started to disintegrate at $>65^{\circ} \mathrm{C}$ (Fig. 3). This suggests that once the granules are released from the physical barriers within the corn kernel during alkaline processing, their thermal stabilities were comparable to those of corn starch granules isolated by wet milling (Fig. 4). Most protein and endosperm particles remained attached to starch granules even after phase transition (Fig. 3) in masa.

The DSC results from masa, starch isolated from masa by Method 2, native white corn starch (isolated by wet milling), and raw corn starch are shown in Table II. The results indicate that both masa preparation and wet-milling processes affect starch structure. Gomez et al (1992) indicated that starch granules undergo annealing during nixtamalization. Starch annealing involves heating starch granules with sufficient hydration below their gelatinization onset temperatures $\left(T_{0}\right)$ to facilitate molecular mobility (Krueger et al 1987; Tester et al 2001; Qi et al 2004). The annealing process is defined as incubation of starch granules in excess $(>60 \%, w / w)$ or at intermediate $(40-55 \%, w / w)$ water content during a certain period of time (generally $>12 \mathrm{hr}$ ) at a temperature above the glass transition temperature but below the gelatinization temperature (Jacobs and Delcour 1998). During annealing, granule composition and morphology remain essentially unchanged but gelatinization peak temperature $\left(T_{\mathrm{p}}\right)$ increases significantly
(Krueger et al 1987; Tester and Debon 2000; Tester et al 2001; Gomes et al 2004; Qi et al 2004; Kohyama and Sasaki 2006). The observed DSC differences among wet-milled starch, starch isolated from masa (Table II), and raw starch from corn kernels indicate that the effect of thermal events on starch granules during masa preparation is somewhat different from the classical changes, in terms of DSC parameters, expected in annealing. Previous reports have also suggested that wet-milling unit operations cause annealing in starch granules (Perez et al 2001; Wang et al 2006). The narrowed DSC transition temperature range and increased enthalpy between raw starch (hand-scraped endosperm) and wet-milled starch indicates that the wet-milled starch exhibits some characteristics of annealing during wet milling, but the unchanged $T_{\mathrm{p}}$ indicates that the effects of wet milling on starch structure are not exactly the same as that of classic annealing. A comparison of DSC parameters of masa and raw starch (scraped endosperm) suggests an even more complex hydrothermal effect on starch structure during masa preparation. Increased $T_{\mathrm{p}}$, increased transition temperature range, and unchanged enthalpy in masa, compared with raw starch, do not match the changes expected in annealing but are somewhat similar to a heat-moisture treatment. Heat-moisture treatment is characterized by processes that involve incubation of starch granules at low $(<35 \%$, w/w) moisture levels and at temperatures above the sample's glass transition temperature (Jacobs and Delcour 1998). Heat-moisture treated starch shows unchanged or widened DSC transitions $\left(T_{\mathrm{c}}-T_{\mathrm{o}}\right)$ and decreased enthalpies $(\Delta H)$ (Hoover and Vasanthan 1994; Jacobs and Delcour 1998). During cooking, whole corn kernels take a period of time to hydrate. Given that properly processed nixtamal has moisture contents of $46-51 \%$ (Sahai et al 2001), it is reasonable to assume that the moisture content of the kernel's starchy endosperm is $<35 \%$ for a considerable time period while
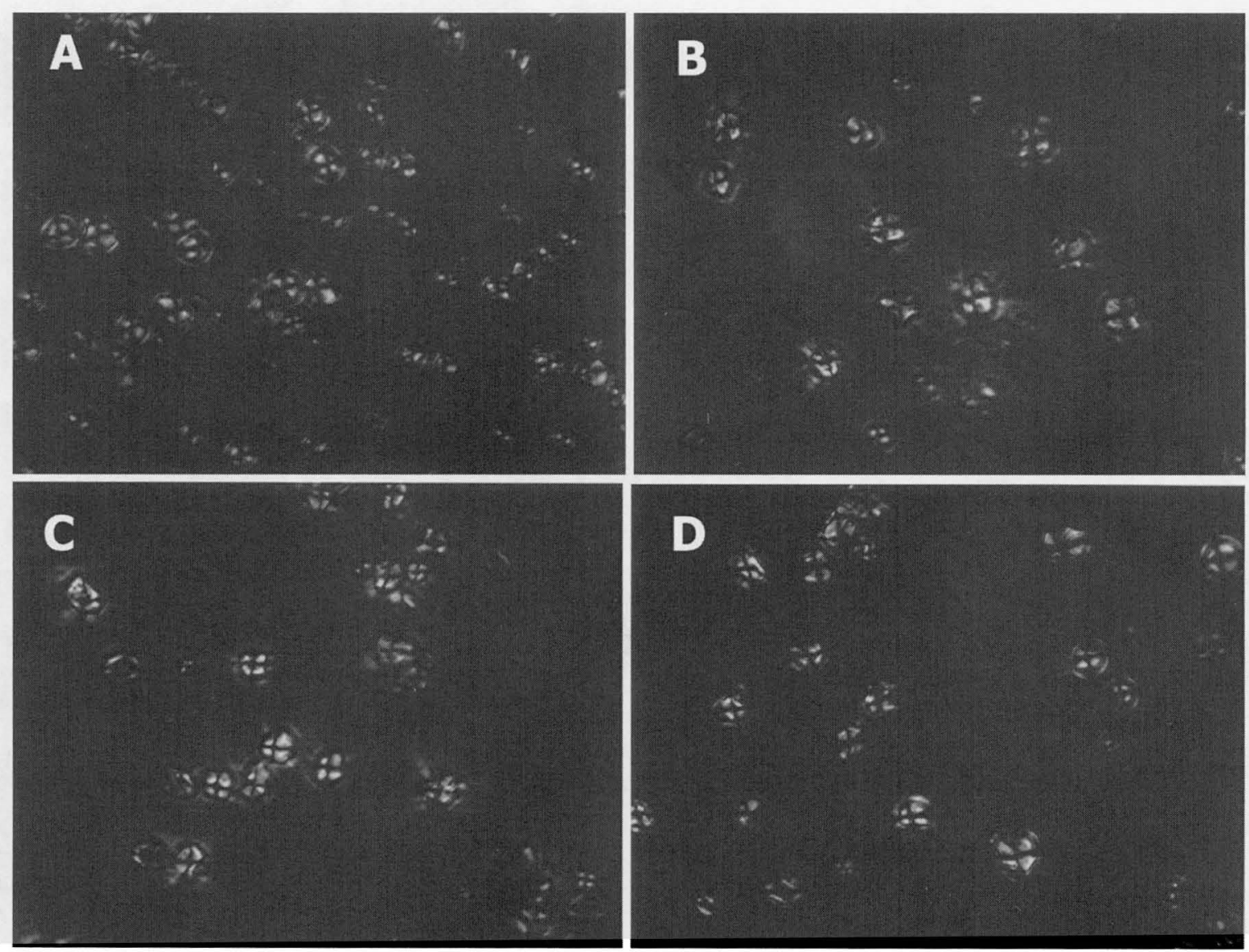

Fig. 2. Polarized light microscopic images of starch from white corn wet milling (A), masa (B), starch isolated from masa by Method 1 (C), and starch isolated from masa by Method 2 (D). Magnification 400x. 
the kernels are being cooked (for $30 \mathrm{~min}$ at $90^{\circ} \mathrm{C}$ ) and steeped for $9.5 \mathrm{hr}$ while cooling from 90 to $25^{\circ} \mathrm{C}$. Although the nixtamalization cooking temperature was slightly lower than typical heat-moisture treatment temperatures $\left(\approx 100^{\circ} \mathrm{C}\right)$ used by many researchers (Hoover and Vasanthan 1994; Anderson et al 2002), given that polymer mobility increases at the (final) higher moisture contents of nixtamal, it is likely that the heat treatment during masa preparation (cooking and steeping) was sufficient to cause a heat-moisture treatment effect on starch granules that are not highly hydrated. Therefore, the heat effect on starch granules, while they are in a low moisture environment, might have caused the observed DSC differences that are comparable to those of heat-moisture-treated starch. DSC transition temperatures and enthalpy of masa (Table II) were different from the previously reported values of $T_{\mathrm{o}}=53.03^{\circ} \mathrm{C}, T_{\mathrm{p}}=62.33^{\circ} \mathrm{C}, T_{\mathrm{c}}=66.4^{\circ} \mathrm{C}$, and $\Delta H=11.1 \mathrm{~J} / \mathrm{g}$ for yellow corn masa by Yglesias and Jackson (2005). This might be due to variations that can be normally attributed to using different corn samples (Table II).

The X-ray patterns of native corn starch, masa, and starch isolated from masa are given in Fig. 5. Both masa and starch showed typical A-type XRD patterns as reported by others (Gomez et al 1991, 1992; Bello-Perez et al 2003). The relative crystallinities of masa starch (by Method 2) and corn starch (from wet milling) were $53.4 \%$ (SD 1.4\%) and 64.8\% (SD 10.3\%), respectively. These

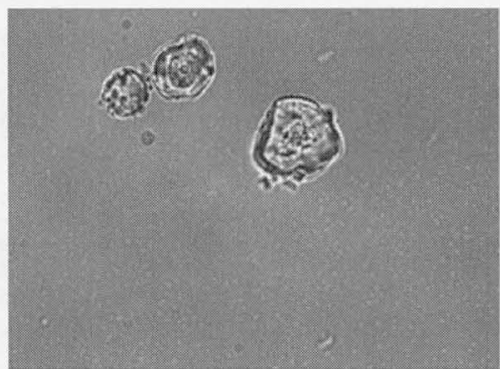

Room temp

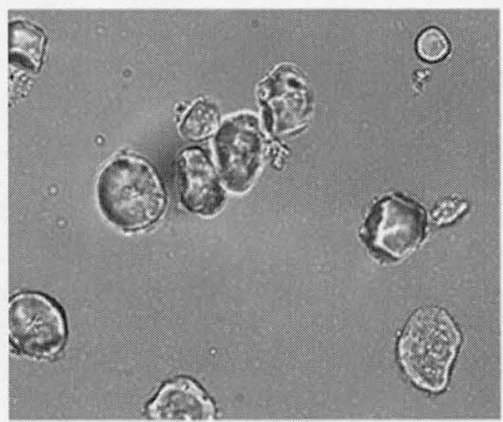

$45^{\circ} \mathrm{C}$

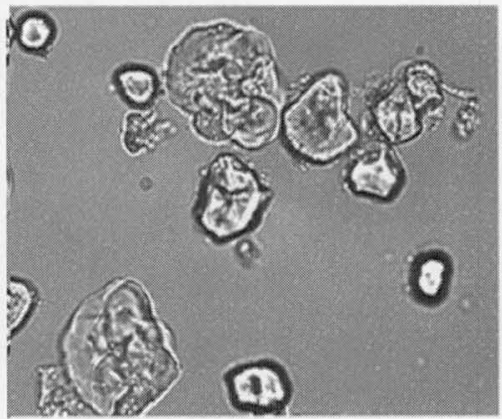

$60^{\circ} \mathrm{C}$

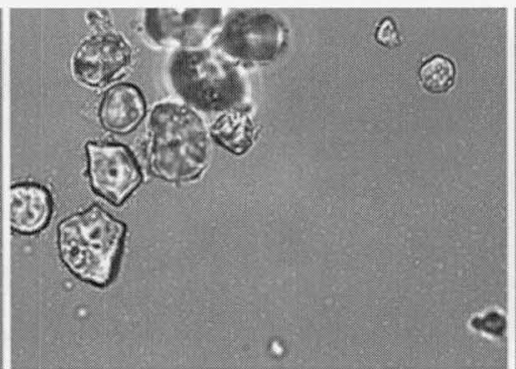

$35^{\circ} \mathrm{C}$

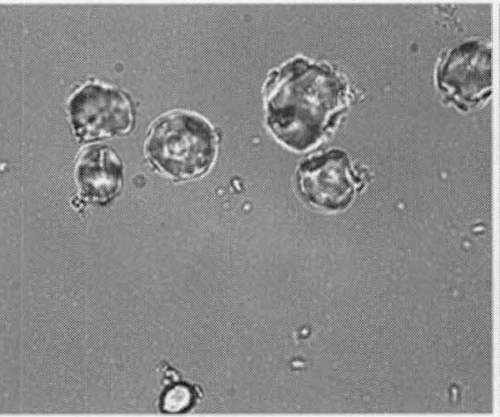

$50^{\circ} \mathrm{C}$

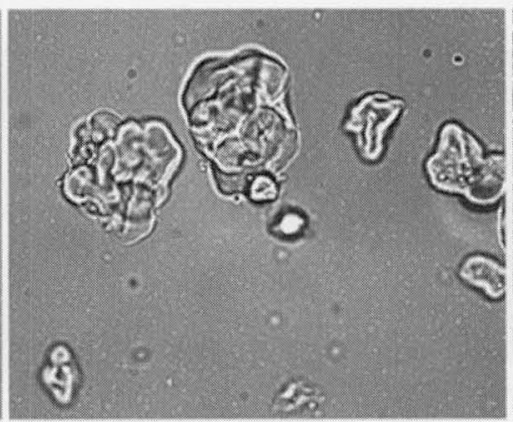

$65^{\circ} \mathrm{C}$

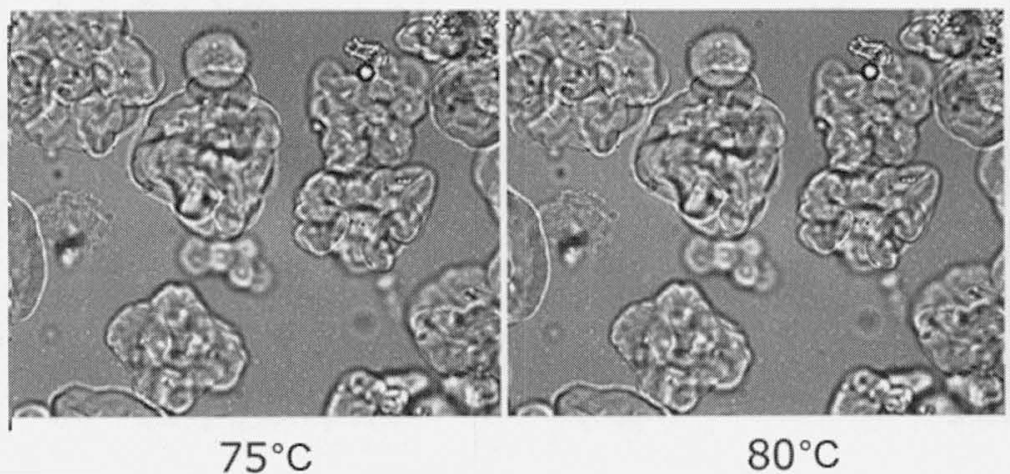

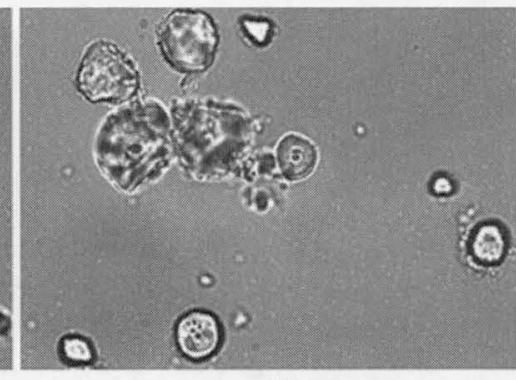

$40^{\circ} \mathrm{C}$

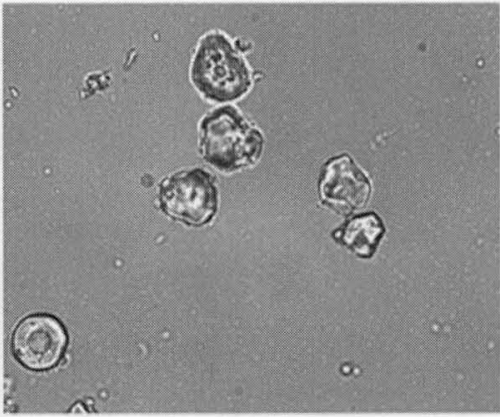

$55^{\circ} \mathrm{C}$

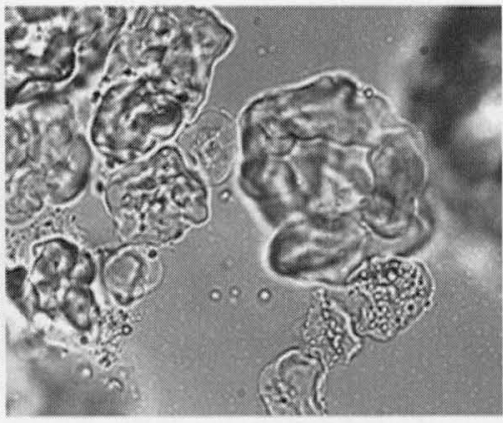

$70^{\circ} \mathrm{C}$

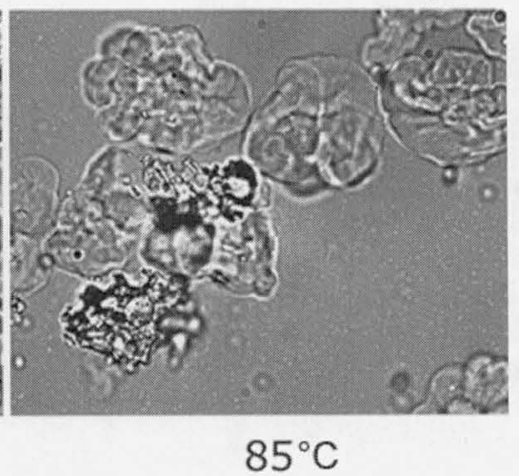

Fig. 3. Light microscopic images of masa heated to specific temperatures in excess water. Magnification $600 \times$. 


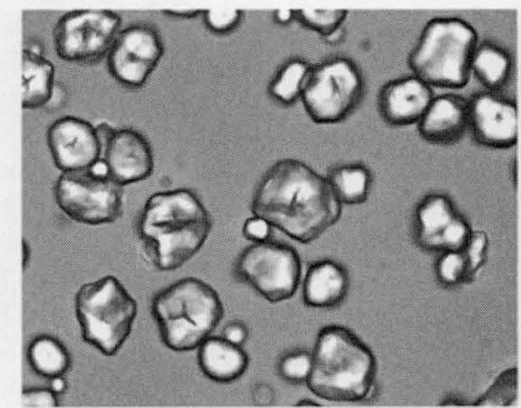

Room temp

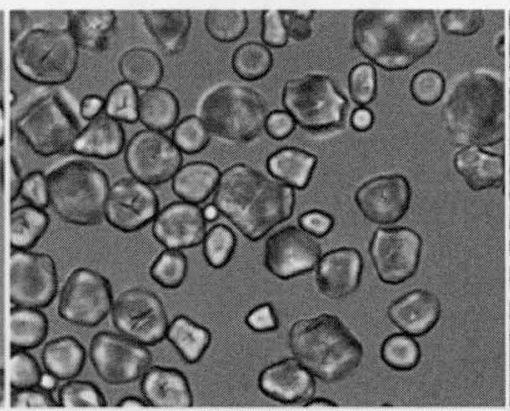

$35^{\circ} \mathrm{C}$

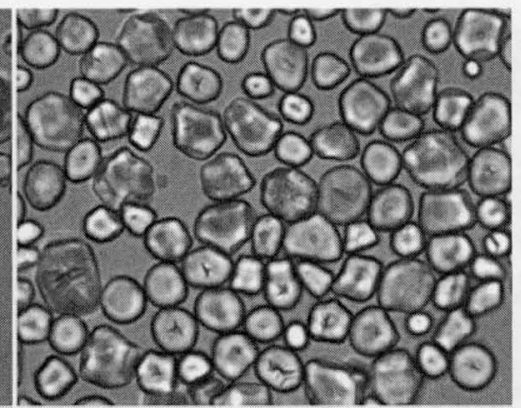

$40^{\circ} \mathrm{C}$

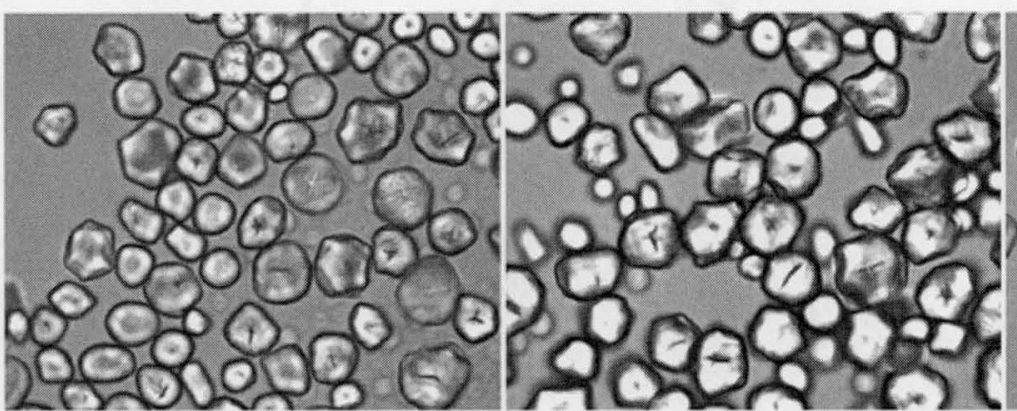

$45^{\circ} \mathrm{C}$

$50^{\circ} \mathrm{C}$

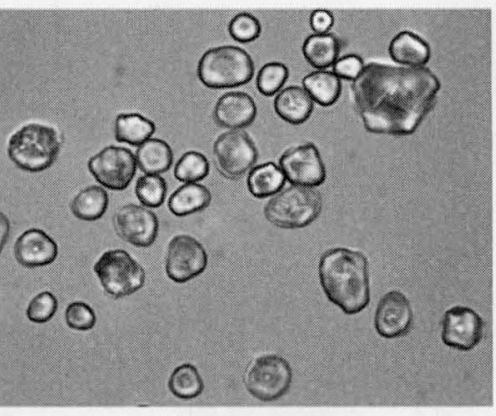

$55^{\circ} \mathrm{C}$
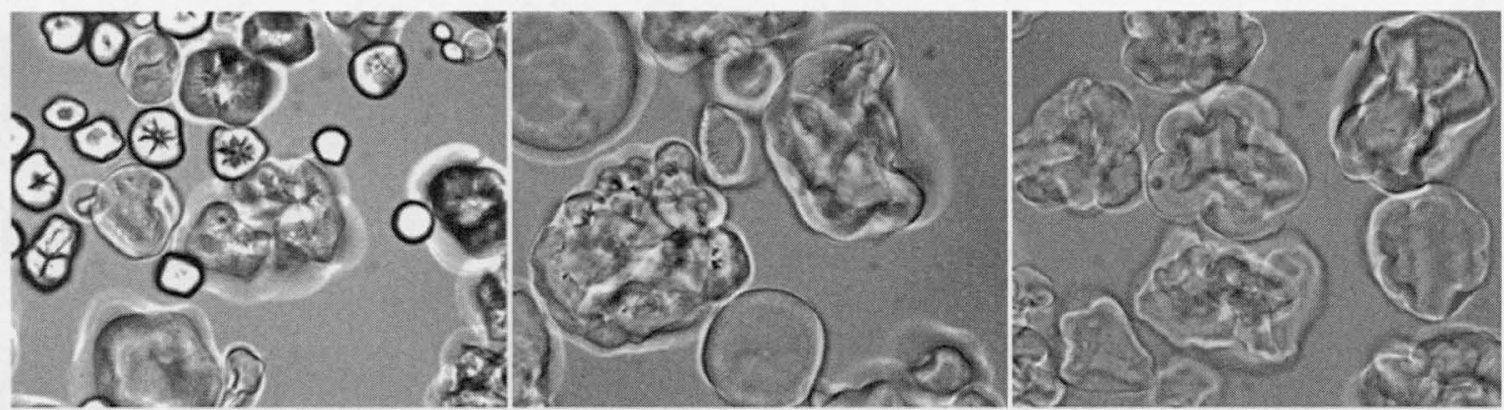

$60^{\circ} \mathrm{C}$

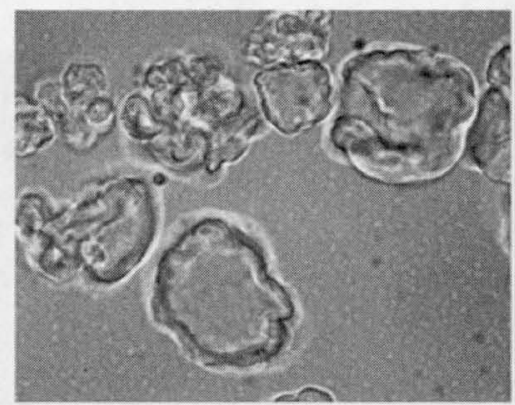

$75^{\circ} \mathrm{C}$ $65^{\circ} \mathrm{C}$

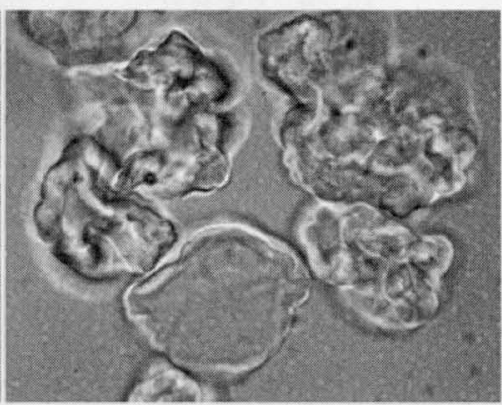

$80^{\circ} \mathrm{C}$ $70^{\circ} \mathrm{C}$

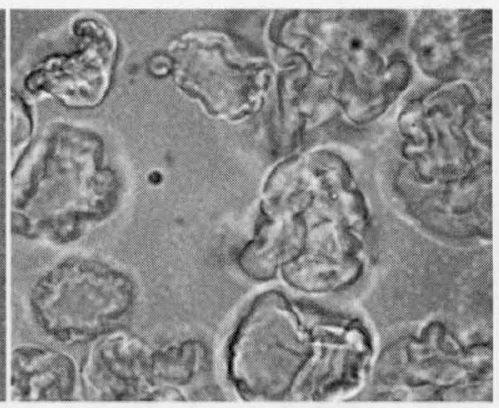

$85^{\circ} \mathrm{C}$

Fig 4. Light microscopic images of untreated starch from corn wet milling heated to specific temperatures in excess water. Magnification $600 \times$.

values (just like the DSC values mentioned earlier) are relatively higher than those reported for regular corn starch, which are generally $\leq 30 \%$ (Nara et al 1978; Cheetham and Tao 1998; Ratnayake 2006). The higher crystallinity of corn starch might be a characteristic attributed to the $1851 \mathrm{~W}$ corn hybrid. It is likely that starch granules, when heated to high temperatures during nixtamalization, with physical protection from the surrounding endosperm protein matrix, have undergone intermolecular changes to decrease crystallinity and lose birefringence while retaining the general shape of the granule.

The relative crystallinity of masa was $\approx 44 \%$ (SD $4.3 \%$ ) which is slightly higher than previously reported values $(\approx 30 \%$ by
Yglesias and Jackson 2005). This may be due to the differences in the source of corn (white corn hybrid Zimmerman $1851 \mathrm{~W}$ in this study vs. yellow corn hybrid Pioneer 34K77 used previously). The XRD peaks were less intense in masa compared with those of both isolated and wet-milled starch $(44,53.4$, and $64.8 \%$ relative crystallinity, respectively) (Fig. 5). It is likely that completely gelatinized or damaged granules are lost during isolation and purification, which would have contributed to the $26 \%$ loss in recovered starch from masa when granules were isolated by Method 2. Such isolation loses would contribute to an increase in crystallinity in isolated starch compared with masa because the gelatinized or damaged granules lost during isolation are less crystalline. 
TABLE II

Differential Scanning Calorimetric Parameters of Masa and Starch Isolated from Masa ${ }^{\mathrm{a}}$

\begin{tabular}{llllcc}
\hline Sample & $\boldsymbol{T}_{\mathbf{o}}\left({ }^{\circ} \mathrm{C}\right)$ & $\boldsymbol{T}_{\mathrm{p}}\left({ }^{\circ} \mathrm{C}\right)$ & $\boldsymbol{T}_{\mathbf{c}}\left({ }^{\circ} \mathrm{C}\right)$ & $\boldsymbol{T}_{\mathbf{c}}-\boldsymbol{T}_{\mathbf{o}}\left({ }^{\circ} \mathrm{C}\right)$ & $\Delta H(\mathrm{~J} / \mathrm{g})$ \\
\hline $\begin{array}{l}\text { Masa } \\
\begin{array}{c}\text { Starch isolated } \\
\text { from masa }\end{array}\end{array}$ & $74.1 \mathrm{ab}$ & $80.0 \mathrm{a}$ & $87.0 \mathrm{a}$ & $12.9 \mathrm{a}$ & $8.6 \mathrm{c}$ \\
$\begin{array}{c}\text { Native white } \\
\text { corn starch }\end{array}$ & $74.4 \mathrm{a}$ & $78.4 \mathrm{ab}$ & $84.8 \mathrm{ab}$ & $10.4 \mathrm{c}$ & $11.5 \mathrm{~b}$ \\
$\begin{array}{c}\text { Raw starch from } \\
\text { corn kernels }\end{array}$ & $72.4 \mathrm{~b}$ & $77.3 \mathrm{~b}$ & $83.7 \mathrm{bc}$ & $11.3 \mathrm{~b}$ & $8.7 \mathrm{c}$ \\
\hline
\end{tabular}

a Values followed by the same letters in the same column are not significantly different $(P>0.05)$ by Tukey-Kramer HSD test. Ranges of standard deviations were $0.25-0.50$ for $T_{\mathrm{o}}, T_{\mathrm{p}}$, and $T_{\mathrm{c}} ; 0.10-0.25$ for $T_{\mathrm{c}}-T_{\mathrm{o}}$; and $0.35-0.54$ for $\Delta H$.

b Using Method 2.

c Isolated form white corn by wet milling.

${ }^{\mathrm{d}}$ Manually scraped from corn kernels.

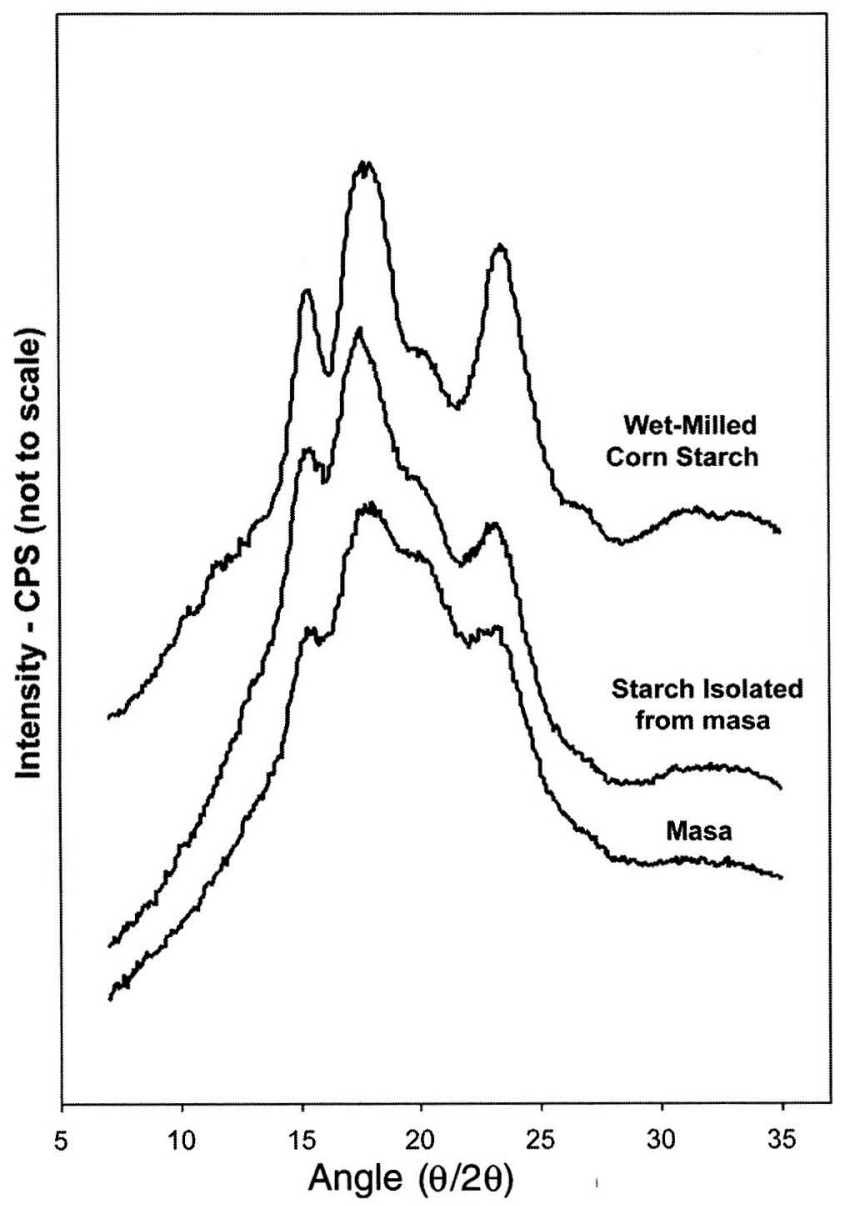

Fig. 5. Representative XRD patterns (isolated masa starch from Method 2).

\section{CONCLUSIONS}

Nixtamalization and masa preparation change the structure of starch granules without causing viewable morphological changes of those granules ( $74 \%$ of the total starch) that can be easily isolated in relatively pure form using thermolysin [EC 3.4.24.27] enzyme. The hydrothermal effect on intact starch granules during these processes is similar to what are known as annealing and heat-moisture treatment, although neither exactly meets the classic definitions of these phenomena. Approximately $26 \%$ of the total masa starch was lost during the isolation process; much of this lost starch had probably been subjected to thermal degradation (gelatinization) or mechanical damage.
In summary, our results conclude that the traditional masa preparation process does not uniformly affect all the starch granules in masa. Some granules partially or completely gelatinize during the process, while the majority $(\approx 76 \%)$ of them survive through the process with minimal morphological/physical damage but with varying degrees of internal structural modifications. Starch isolation using thermolysin results in relatively pure granules; this isolation process, however, causes slight structural changes.

\section{ACKNOWLEDGMENTS}

We wish to thank Kit Lee, You Zhou, Terri Fangman (Microscopy Core Facility, Beadle Center, University of Nebraska-Lincoln) and Samudra Wijeratne and Andreia Bianchini (Department of Food Science and Technology) for assistance in microscopy; Brian Jones (Center for Materials Research and Analysis, Behlen Laboratory, University of Nebraska-Lincoln) for technical assistance in XRD experiments, and Roxana Yglesias for assistance in nixtamalization and masa preparation.

\section{LITERATURE CITED}

Anderson, A. K., Guraya, H. S., James, C., and Salvaggio, L. 2002. Digestibility and pasting properties of rice starch heat-moisture treated at the melting temperature $T_{\mathrm{m}}$. Starch/Stärke 54:401-409.

AOAC International. 2004. Official Methods of Analysis of AOAC International. 18th Ed. AOAC International: Gaithersburg, MD.

Belles, A. M., Montville, T. J., and Wasserman, B. P. 2000. Enzymatic removal of zeins from the surface of maize starch granules. J. Ind. Microbiol. Biotechnol. 24:71-74.

Bello-Perez, L. A., Osorio-Diaz, P., Agama-Acevedo, E., Solorza-Feria, J., Toro-Vazquez, J. F., and Paredes-Lopez, O. 2003. Chemical and physicochemical properties of dried wet masa and dry masa flour. J. Sci. Food Agric. 83:408-412.

Biliaderis, C. G. 1998. Structures and phase transitions of starch polymers. Pages 57-168 in: Polysaccharide Association Structures in Food. R. H. Walter, ed. Marcel Dekker: New York.

Bogracheva, T. Y., Wang, Y. L., Wang, T. L., and Hedley, T. L. 2002. Structural studies of starches with different water contents. Biopolymers 64:268-281.

Bryant, C. M., and Hamaker, B. R. 1997. Effect of lime on gelatinization of corn flour and starch. Cereal Chem. 74:171-175.

Campus-Baypoli, O. N., Rosas-Burgos, E. C., Torres-Chavez, P. I., RamirezWong, B., and Serna-Saldivar, S. O. 1999. Physicochemical changes of starch during maize tortilla production. Starch/Stärke 51:173-177.

Cheetham, N. W. H., and Tao, L. 1998. Variation in crystalline type with amylose content in maize starch granules: An X-ray powder diffraction study. Carbohydr. Polym. 36:277-284.

Eliasson, A.-C. 1985. Starch gelatinization in the presence of emulsifiers. Starch/Stärke 37:411-415.

Eliasson, A. C., Larsson, K., Andersson, S., Hyde, S. T., Nesper, R., and von Schnering, H. G. 1987. On the structure of native starch-An analogue to quartz structure. Starch/Stärke 39:147-152.

Gibbon, B. C., Wang, X., and Larkins, B. A. 2003. Altered starch structure is associated with endosperm modification in quality protein maize. PNAS 100:15329-15334.

Gomes, A. M. M., da Silva, C. E. M., Ricardo, N. M. P. S., Sasaki, J. M., and Germani, R. 2004. Impact of annealing on the physicochemical properties of unfermented cassava starch (Polvilho doce). Starch/Stärke $56: 419-423$

Gomez, M. H., McDonough, C. M., Rooney, L. W., and Waniska, R. D. 1989. Changes in corn and sorghum during nixtamalization and tortilla baking. Cereal Chem. 54:330-336.

Gomez, M. H., Rooney, L. W., Waniska, R. D., and Pflugfelder, R. L. 1987. Dry corn masa flours for tortilla and snack processing. Cereal Foods World 32:372-377.

Gomez, M. H., Waniska, R. D., and Rooney, L. W. 1991. Starch characterization of nixtamalized corn flour. Cereal Chem. 68:578-582.

Gomez, M. H., Lee, J. K., McDonough, C. M., Waniska, R. D., and Rooney, L. W. 1992. Corn starch changes during tortilla and tortilla chip processing. Cereal Chem. 69:275-279.

Gonera, A., and Cornillon, P. 2002. Gelatinization of starch/gum/sugar systems studied by using DSC, NMR, and CSLM. Starch/Stärke $54: 508-516$ 
Han, X.-Z., Benmoussa, M., Gray, J. A., BeMiller, J. N., and Hamaker, B. R. 2005. Detection of proteins in starch granule channels. Cereal Chem. 82:351-355.

Hoover, R., and Vasanthan, T. 1994. Effect of heat-moisture treatment on the structure and physicochemical properties of cereal, legume, and tuber starches. Carbohydr. Chem. 252:33-53.

Jacobs, H., and Delcour, J. A. 1998. Hydrothermal modifications of granular starch with retention of granular structure: A review. J. Agric. Food Chem. 46:2895-2905.

Jenkins, P. J., and Donald, A. M. 1998. Gelatinization of starch: A combined SAXS/WAXS/DSC and SANS study. Carbohydr. Res. 308:133147.

Kar, A., Jacquire, J.-C., Morgan, D. J., Lyng, J. G., and McKenna, B. M. 2005. Influence of lipid extraction process on the rheological characteristics, swelling power, and granule size of rice starches in excess water. J. Agric. Food Chem. 53:8259-8265.

Kohyama, K., and Sasaki, T. 2006. Differential scanning calorimetry and a model calculation of starches annealed at 20 and $50^{\circ} \mathrm{C}$. Carbohydr. Polym. 63:82-88.

Krueger, B. R., Knutson, C. A., Inglett, G. E., and Walker, C. E. 1987. A differential scanning calorimetry study on the effect of annealing on gelatinization behavior of corn starch. J. Food Sci. 52:715-718.

Larsson, K. 1980. Inhibition of starch gelatinization by amylose-lipid complex formation. Starch/Stärke 32:125-126.

Lim, M. H., Wu, H., and Reid, D. S. 2000. The effect of starch gelatinization and solute concentrations on $T_{\mathrm{g}}$ ' of starch model system. J. Sci. Food Agric. 80:1757-1762.

Lindeboom, N., Chang, P. R., and Tyler, R. T. 2004. Analytical, biochemical, and physicochemical aspects of starch granule size, with emphasis on small granule starches: A review. Starch/Stärke 56:89-99.

Liu, Q., Charlet, G., Yelle, S., and Arul, J. 2002. Phase transition in potato starch-water system. I. Starch gelatinization at high moisture level. Food Res. Int. 35:397-407.

Lund, D., and Lorenz, K. J. 1984. Influence of time, temperature, moisture, ingredients, and processing conditions on starch gelatinization. Crit. Rev. Food Sci. Nutr. 20:249-273.

Mezo-Villanueva, M., and Serna-Saldivar, S. O. 2004. Effect of protease addition on starch recovery from steeped sorghum and maize. Starch/ Stärke 56:371-378

Mondagon, M., Bello-Perez, L. A., Agama-Acevedo, E., Betancur-Ancona, D., and Pena, J.-L. 2004. Effect of cooking time, steeping and lime concentration on starch gelatinization of corn during nixtamalization. Starch/Stärke 56:248-253.

Mu-Forster, C., and Wasserman, B. P. 1998. Surface localization of zein storage proteins in starch granules from maize endosperm. Plant Physiol. 116:1563-1571.

Nara, S., Mori, A., and Komiya, T. 1978. Study on relative crystallinity of moist potato starch. Starch/Stärke 30:111-114.

Perez, O. E., Haros, M., and Suarez, C. 2001. Corn steeping: Influence of time and lactic acid on isolation and thermal properties of starch. J. Food Eng. 48:251-256.

Qi, X., Tester, R. F., Snape, C. E., Yuryev, V., Wasserman, L. A., and Ansell, R. 2004. Molecular basis for the gelatinisation and swelling characteristics of waxy barley starches grown at the same location during the same season. II. Crystallinity and gelatinisation characteristics. J. Cereal Sci. 39:57-66.

Ratnayake, R. M. W. S. 2006. A new insight into the phase transition processes of food starches. PhD dissertation. University of NebraskaLincoln: Lincoln, NE.

Ratnayake, W. S., and Jackson, D. S. 2006. Gelatinization and solubility of corn starch during heating in excess water: New insights. J. Agric. Food Chem. 54:3712-3716.

Rumpold, B. A., and Knorr, D. 2005. Effect of salts and sugars on pressure-induced gelatinisation of wheat, tapioca, and potato starches. Starch/Stärke 57:370-377.

Sahai, D., and Jackson, D. S. 1999. Enthalpic transition in native starch granules. Cereal Chem. 76:444-448.

Sahai, D., Mua, J. P., Surjewan, I., Buendia, M. O., Rowe, M., and Jackson, D. S. 2001. Alkaline processing (nixtamalization) of white Mexican corn hybrids for tortilla production: Significance of corn physiochemical characteristics and process conditions. Cereal Chem. 78:116-120.

Sayer, S., Koksel, H., and Turhan, M. 2005. The effects of protein-rich fraction and defatting on pasting behavior of chickpea starch. Starch/ Stärke 57:599-604.

Serna-Saldivar, S. O., Gomez, M. H., and Rooney, L. W. 1990. Technology, chemistry, and nutritional value of alkaline-cooked corn products. Pages 243-307 in: Advances in Cereal Science and Technology. Vol. X. Y. Pomeranz, ed. AACC International: St. Paul, MN.

Tester, R. F., and Debon, S. J. J. 2000. Annealing of starch-A review. Int. J. Biol. Macromol. 27:1-12.

Tester, R. F., Debon, S. J. J., Qi, X., Sommerville, M. D., Yousuf, R., and Yusuph, M. 2001. Amylopectin crystallisation in starch. Pages 97-102 in: Starch: Advances in Structure and Function. T. L. Barsby, A. M. Donald, and P. J. Frazier, eds. R. Soc. Chem.: Cambridge.

Tolstoguzov, V. 2003. Thermodynamic considerations of starch functionality in foods. Carbohydr. Polym. 51:99-111.

Wang, Y.-J., Chong, S. W., and Yang, W. 2006. Effect of pericarp removal on properties of wet-milled corn starch. Cereal Chem. 83:25-27.

Wehling, R. L., Jackson, D. S., Hooper, D. G., and Ghaedian, A. R. 1993. Prediction of wet-milling starch yield from corn by near-infrared spectroscopy. Cereal Chem. 70:720-723.

Yglesias, R., and Jackson, D. S. 2005. Evaluation of liquid nitrogen freeze drying and ethanol dehydration as methods to preserve partially cooked starch and masa systems. Cereal Chem. 82:702-705.

Yglesias, R., Parkhurst, A. M., and Jackson, D. S. 2005. Development of laboratory techniques to mimic industrial-scale nixtamalization. Cereal Chem. 82:695-701.

Zhang, G., and Hamaker, B. R. 2003. A three component interaction among starch, protein, and free fatty acids revealed by pasting profiles. J. Agric. Food Chem. 51:2797-2800.

Zhang, G., Maladen, M. D., and Hamaker, B. R. 2003. Detection of a novel three component complex consisting of starch, protein and free fatty acids. J. Agric. Food Chem. 51:2801-2805.

Zobel, H. F. 1984. Gelatinization of starch and mechanical properties of starch pastes. Pages 285-309 in: Starch Chemistry and Technology, 2nd Ed. R. L. Whistler, J. N. BeMiller, and E. Paschall, eds. Academic Press: Orlando, FL. 